\title{
Effect of Renal Vein Variations on Apparent Diffusion Coefficient in Asymptomatic Patients
}

\section{Asemptomatik Hastalarda Renal Ven Varyasyonlarının Böbrek Görünür Difüzyon Katsayısı Değerlerine Etkisi}

\author{
๑ Elif Gündoğdu, ๑ Emre Emekli, • Mehmet Oğuzman, ๑ Mahmut Kebapçı
}

Eskişehir Osmangazi University Faculty of Medicine, Department of Radiology, Eskişehir, Turkey

\section{Abstract}

Aim: The aim of this study was to investigate whether renal vein variations had an effect on apparent diffusion coefficient (ADC) values in diffusion magnetic resonance imaging (MRI).

Methods: Images of 958 patients who underwent MRI between January 2017 and October 2018 were retrospectively evaluated for renal vein variations based on the records obtained from the image archive. Forty-six patients with renal vein variations and thirty patients of similar age and gender as the control group enrolled in the study. The ADC values of both kidneys were measured at low-high b values.

Results: The ADC values in the left kidney were lower than in the right kidney in both groups $\left(2.04 \times 10^{-3} \pm 0.22 \times 10^{-3} \mathrm{~mm}^{2} / \mathrm{sec}\right.$, $1.96 \times 10^{-3} \pm 0.17 \times 10^{-3} \mathrm{~mm}^{2} / \mathrm{sec}$, for the renal vein variation group; $\mathrm{p}=0.008$ and $2.08 \times 10-3 \pm 0.13 \times 10^{-3} \mathrm{~mm}^{2} / \mathrm{sec}, 1.94 \times 10^{-3} \pm 0.11 \times 10^{-3}$ $\mathrm{mm}^{2} / \mathrm{sec}$, for the control group; $\left.\mathrm{p}=0.0001\right)$. However, no significant difference was found between the renal vein variation and control groups in terms of the ADC values in both kidneys.

Conclusion: Renal vein variations had no effect on renal ADC values in asymptomatic patients. Further studies can provide additional information for symptomatic patient groups.

Keywords: Renal vein variations, diffusion magnetic resonance imaging, ADC

\section{Öz}

Amaç: Bu çalışmanın amacı, renal ven varyasyonlarının difüzyon ağırlıklı manyetik rezonans görüntülemede (MRG) görünür difüzyon katsayısına (GDK) etkisinin olup olmadığını araştırmaktadır.

Yöntemler: Ocak 2017 ile Ekim 2018 tarihleri arasında abdominal MRG çekilmiş 958 hastanın tetkikleri renal ven varyasyonları açısından hastane görüntü arşivinden retrospektif olarak incelendi. Renal ven varyasyonu olan 46 hasta ve 30 hastadan oluşan kontrol grubunda yüksek ve düşük b değerlerinde her iki böbreğin GDK değerleri ölçüldü.

Bulgular: Renal ven varyasyonu olan grupta ve kontrol grubunda sağ ve sol böbrek GDK değerleri arasında fark saptandı $\left[2,04 \times 10^{-3} \pm 0,22 \times 10^{-3} \mathrm{~mm}^{2} / \mathrm{sec}, 1,96 \times 10^{-3} \pm 0,17 \times 10^{-3} \mathrm{~mm}^{2} / \mathrm{sec}\right.$; $\mathrm{p}=0.008$ (varyasyonu olan grupta sağ ve sol böbrek, sırasıyla), $2,08 \times 10^{-3} \pm 0,13 \times 10^{-3} \mathrm{~mm}^{2} / \mathrm{sec}, 1,94 \times 10^{-3} \pm 0,11 \times 10^{-3} \mathrm{~mm}^{2} / \mathrm{sec}$; $p=0,0001$, kontrol grubunda sağ ve sol böbrek, sırasıyla]. Sol böbrek GDK değerleri her iki grupta da sağ böbrekten daha düşüktü. Her iki böbrek GDK değerleri renal ven varyasyonu olan grupta ve kontrol grubunda benzerdi.

Sonuç: Renal ven varyasyonu asemptomatik hastalarda böbrek GDK değerleri üzerinde herhangi etki göstermemektedir. Gelecekte semptomatik hasta gruplarıyla yapılacak çalışmalar ek bilgi verebilir.

Anahtar Sözcükler: Renal ven varyasyonları, difüzyon manyetik rezonans görüntüleme, GDK
Address for Correspondence/Yazışma Adresi: Emre Emekli, Eskişehir Osmangazi University Faculty of Medicine, Department of Radiology, Eskişehir, Turkey

Phone: +90 2222293979 E-mail: emreemekli90@gmail.com ORCID: orcid.org/0000-0001-5989-1897

Received/Geliş Tarihi: 07 July 2020 Accepted/Kabul Tarihi: 12 October 2020

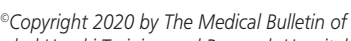
istanbul Haseki Training and Research Hospital The Medical Bulletin of Haseki published by Galenos Yayınevi. ${ }^{\circledR}$ Telif Hakkı 2020 İstanbul Haseki Eğitim ve Araştırma Hastanesi Haseki Tip Bülteni, Galenos Yayınevi tarafından yayınlanmıştır. 


\section{Introduction}

Left renal vein and inferior vena cava variations are relatively frequent compared to those of the right renal vein due to the complexity of embryological development (1). The most common left renal vein variations are observed in the retroaortic and circumaortic renal veins. Renal vein variations are generally asymptomatic and frequently discovered incidentally $(1,2)$. However, in some cases, increased venous pressure due to compression between the vertebrae and the aorta may cause symptoms, such as left side pain, hematuria, and proteinuria $(3,4)$. It has also been reported that renal vein variations may be associated with left-sided varicoceles, pelvic congestion syndrome, dyspareunia, and dysmenorrhea $(5,6)$. Recently, the prevalence of incidentally detected renal vein variations has increased due to the increased use of imaging techniques.

Magnetic resonance imaging (MRI) can noninvasively assess the kidney structure and function in a single screening session. It is possible to evaluate the microstructure of the kidney using diffusion-weighted imaging (DWI), which evaluates the Brownian motion of water molecules in the tissue and allows the quantification of motion based on the apparent diffusion coefficient (ADC) $(7,8)$. There are many human studies concerning the use of DWI in diffuse renal pathologies (9). There are also studies conducting DW MRI in patients with acute renal failure, acute pyelonephritis, acute graft dysfunction, polycystic disease, amyloidosis, diabetes, various glomerulonephritis, obstruction, renal artery stenosis, and other various etiologies (10). These studies revealed changes in renal parenchyma, such as edema and fibrosis using DW MRI and ADC values.

It is suggested that renal vein variations can cause venous hypertension, which may also be responsible for symptoms. If venous hypertension due to venous variation causes changes in the kidney ADC values, this parameter can be used in the diagnosis and follow-up of these patients. In this study, we aimed to evaluate whether left renal vein variations caused changes in the kidney ADC values.

\section{Methods}

\section{Study Subjects}

Ethics committee approval was obtained from Eskişehir Osmangazi University Faculty of Medicine (date: 27.11.2018, no: 25403353-050.99-E.128703) and the study was conducted in accordance with the Declaration of Helsinki. The study involved retrospective reevaluation of the upper abdominal MRI recorded between January 2017 and October 2018, obtained from the hospital image archive. Upper abdominal MRI performed in patients with non-urinary system indications (chronic liver parenchymal disease, focal lesion in liver parenchyma, choledocholithiasis, adrenal lesion, pancreatic lesions, etc.) were included in the study. Patients with renal dysfunction and solitary kidneys, and those with images that could not be evaluated for technical reasons (motion artefacts, MRI without diffusion examination at an appropriate value of b) were excluded from the study. As a result, the MRI images of 958 patients, comprising 498 (52\%) females and $460(48 \%)$ males were evaluated. The flowchart is presented in Figure 1.

None of the patients had any urinary symptom or pathological finding in urinalysis. Their serum urea and creatinine values were also normal. The presence and type (circumaortic, retroaortic) of left renal vein variations were recorded. Thirty patients of similar age and gender without renal vein variations were selected to form the control group. Renal function values were normal in the control group. The serum urea and creatinine values and urine analysis were also within the normal range.

\section{Magnetic Resonance Imaging}

MRI was performed using a 3-Tesla (General Electric, Milwaukee, WI) device. In all examinations, a 48-channel body coil was used. T2-weighted axial and coronal plane images, T1-weighted axial plane images, and diffusionweighted echo planar images (DW-EPI) were obtained in each patient. The DW sections were obtained in the axial

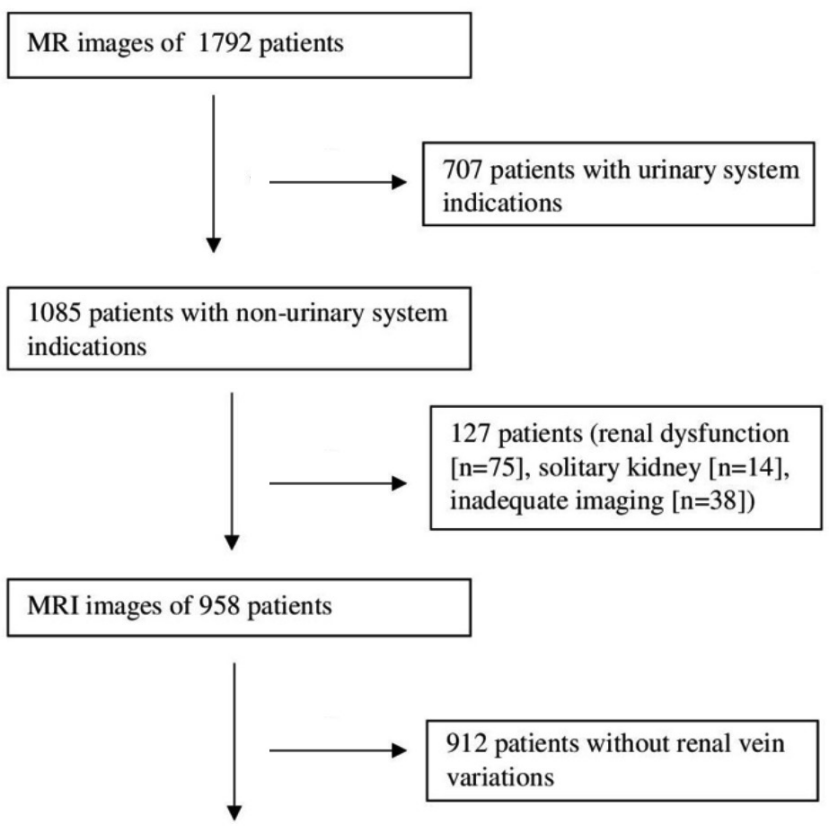

46 patients ( 16 circumaortic, 30

retroaortic)

Figure 1. Recruitment schema of the participants MR: Magnetic resonance 
plane using the DW-EPI sequence at low $\left(b=0 \mathrm{~s} / \mathrm{mm}^{2}\right)$ and high $\left(b=1000 \mathrm{~s} / \mathrm{mm}^{2}\right)$ gradient values without breathholding. The imaging parameters of the DW-EPI sequence were as follows: TR/TE, 9231/64.1; slice thickness, 5 $\mathrm{mm}$; field of view, $42 \mathrm{~cm}$; and matrix size; $98 \times 128$. The $A D C$ value was automatically calculated by the device simultaneously. To prevent bowel movements causing artefacts, MRI was performed after four to six hours of fasting. However, the patients were not given any antispasmolytic.

\section{Analysis of Images}

The images of the patients with renal vein variations and the control group were evaluated using the dedicated workstation (GE, Advantage Workstation 4.3, USA) by two radiologists (one experienced in abdominal imaging) based on consensus. The T1- and T2-weighted images were evaluated for focal kidney lesions. There was no solid renal tumor in patients with renal vein variations. In patients with simple cysts, the levels including the cysts were not included in the measurement. The circular-shaped regions of interest (ROI) with a diameter of $1 \mathrm{~cm}$ were placed in the corticomedullary area in both renal parenchyma (Figure 2, 3). Circular ROI was placed in three regions in the upper, middle and lower sections of the posteromedial of both kidneys. All measurements were undertaken by a single radiologist experienced in abdominal imaging. The measurements were performed twice, and the mean ADC values were used for further evaluation. The diameter of the left renal vein in both the control and renal vein variation groups was measured by the same radiologist

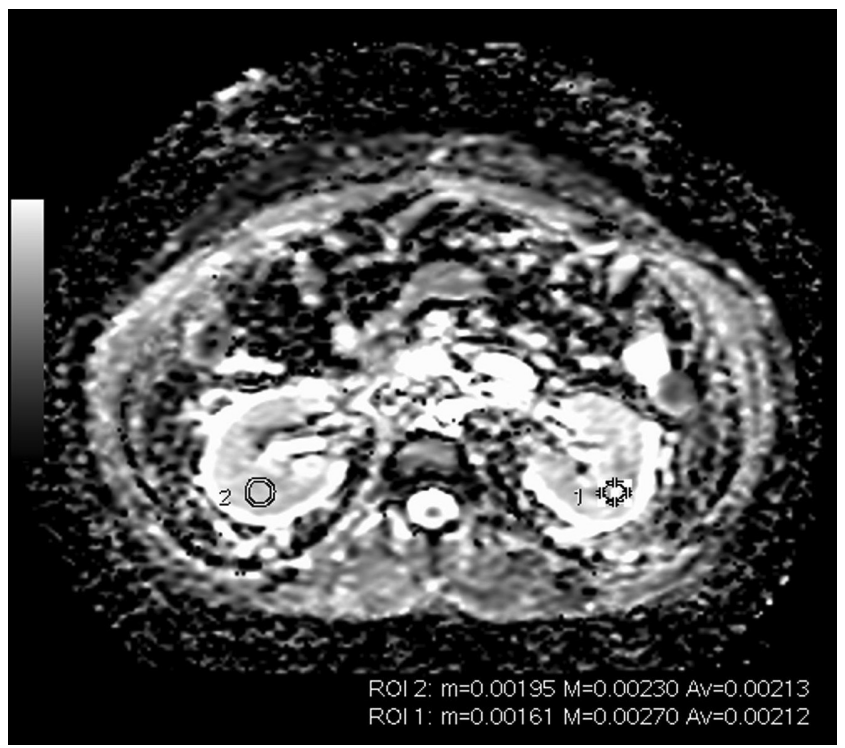

Figure 2. $A D C$ maps $\left(b=1000 \mathrm{~s} / \mathrm{mm}^{2}\right)$ in of a 52 -year-old male in the control group. Regions of interest for the ADC measurements of the right and left kidneys are indicated by white circles $A D C$ : Apparent diffusion coefficient based on the midpoint between the abdominal aorta and the left renal hilum in the axial plane (Figure 4, 5).

\section{Statistical Analysis}

SPSS software v.22.0 (Chicago, IL) was used for statistical analysis. The Shapiro-Wilk test was used for normality testing. Quantitative variables were shown as arithmetic mean \pm standard deviation, and qualitative variables as numbers and percentages. The right and left kidney ADC values in both the control and renal vein variation groups were compared using the Student's t-test. The same test was used to compare the left renal vein diameter between the two groups. The paired samples t-test was used to investigate whether there

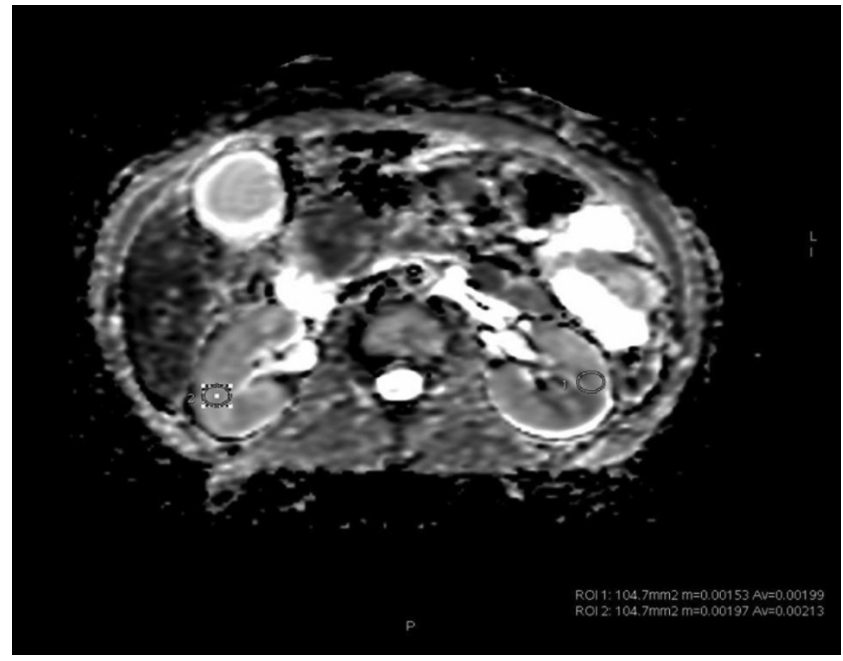

Figure 3. $A D C$ maps $\left(b=1000 \mathrm{~s} / \mathrm{mm}^{2}\right)$ of a 61-year-old male in the renal vein variation group. Regions of interest for the ADC measurements of the right and left kidneys are indicated by white circles

ADC: Apparent diffusion coefficient

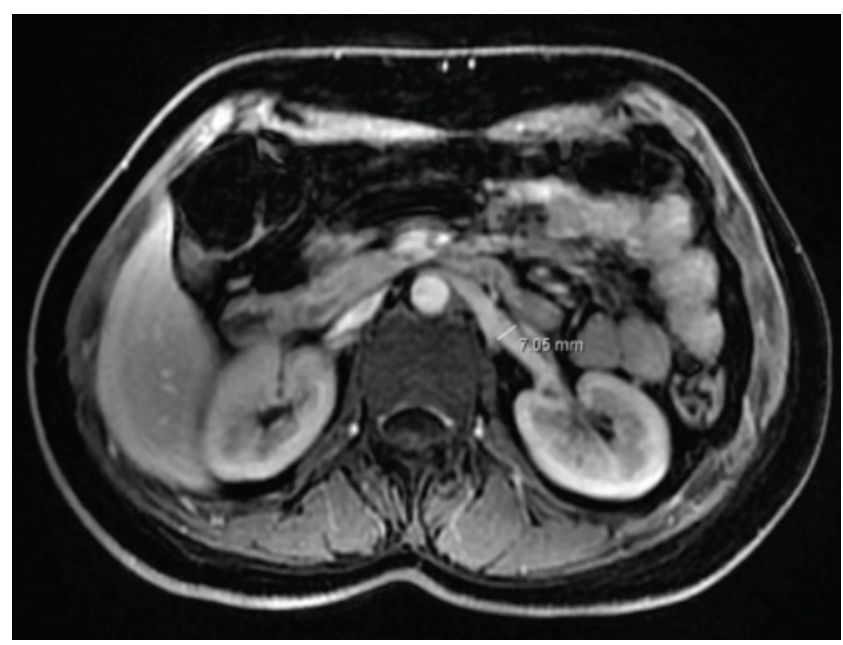

Figure 4. Measurement of the left renal vein diameter on the axial plane images in a 45-year-old female in the control group 
was a difference in the right and left kidney ADC values between the two groups.

\section{Results}

Left renal vein variations were found in 46 (4.80\%) of 958 patients [circumaortic in 16 (Figure 6a and 6b) and retroaortic in 30 (Figure 7 )]. There were 24 women (age range: $23-88$ years; mean age: $58.1 \pm 14.6$ years) and 22 men (age range: $30-92$ years; mean age: $57.7 \pm 16.8$ years) with renal vein variations and 18 women (age range: 27-69 years; mean age: 56.2 \pm 13.6 years), 12 men (age range: $34-77$ years; mean age: $60.5 \pm 14.3$ years) in the control group. There was no difference in age between the groups.

Table 1 presents the comparison of the data between the two groups. The mean ADC of the left kidney was

\begin{tabular}{|l|l|l|l|}
\hline \multicolumn{4}{|l|}{ Table 1. Comparison of data belonging to groups } \\
\hline Parameters & $\begin{array}{l}\text { Renal vein variations } \\
\text { group }\end{array}$ & Control group & $\begin{array}{l}\mathbf{p} \\
\text { value }\end{array}$ \\
\hline $\begin{array}{l}\text { Number of } \\
\text { patients ( } \mathrm{n})\end{array}$ & 46 & 30 & - \\
\hline $\begin{array}{l}\text { Male age/ } \\
\text { female age } \\
\text { (years) }\end{array}$ & $57.7 \pm 16.8 / 58.1 \pm 14.6$ & $60.5 \pm 14.3 / 56.2 \pm 13.6$ & 0.12 \\
\hline $\begin{array}{l}\text { Male/female } \\
\text { (n) }\end{array}$ & $22 / 24$ & $12 / 18$ & - \\
\hline $\begin{array}{l}\text { ADC of right } \\
\text { kidney (mm }{ }^{2} / \\
\text { sec) }\end{array}$ & $2.04 \times 10^{-3} \pm 0.22 \times 10^{-3}$ & $2.08 \times 10^{-3} \pm 0.13 \times 10^{-3}$ & 0.26 \\
\hline $\begin{array}{l}\text { ADC of left } \\
\text { kidney (mm }{ }^{2} / \\
\text { sec) }\end{array}$ & $1.96 \times 10^{-3} \pm 0.17 \times 10^{-3}$ & $1.94 \times 10^{-3} \pm 0.11 \times 10^{-3}$ & 0.71 \\
\hline $\begin{array}{l}\text { Left renal vein } \\
\text { diameter (cm) }\end{array}$ & $7.39 \pm 0.90$ & $7.32 \pm 0.81$ & 0.75 \\
\hline ADC: Apparent diffusion coefficient, $\mathrm{n}$ : Number & \\
\hline
\end{tabular}

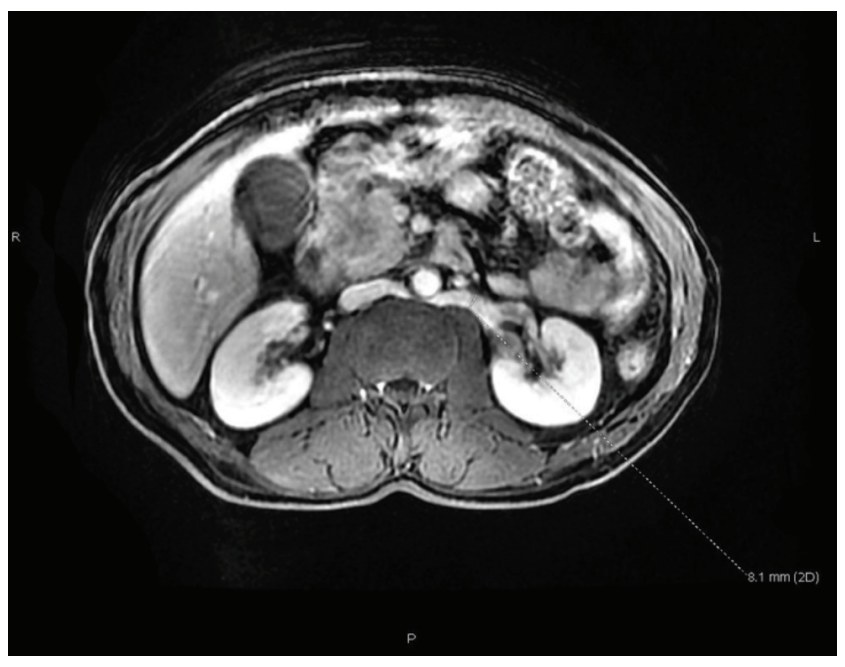

Figure 5. Measurement of the left renal vein diameter on the axial plane images in a 61-year-old male with (retroaortic) renal vein variations lower than that of the right kidney in control group $\mathrm{p}=0.0001)$. The mean ADC of the left kidney was lower than that of the right kidney in renal vein variation group $(p=0.008)$. In the comparison of the right and left kidney $A D C$ values between the renal vein variation and control groups, no significant difference was found.
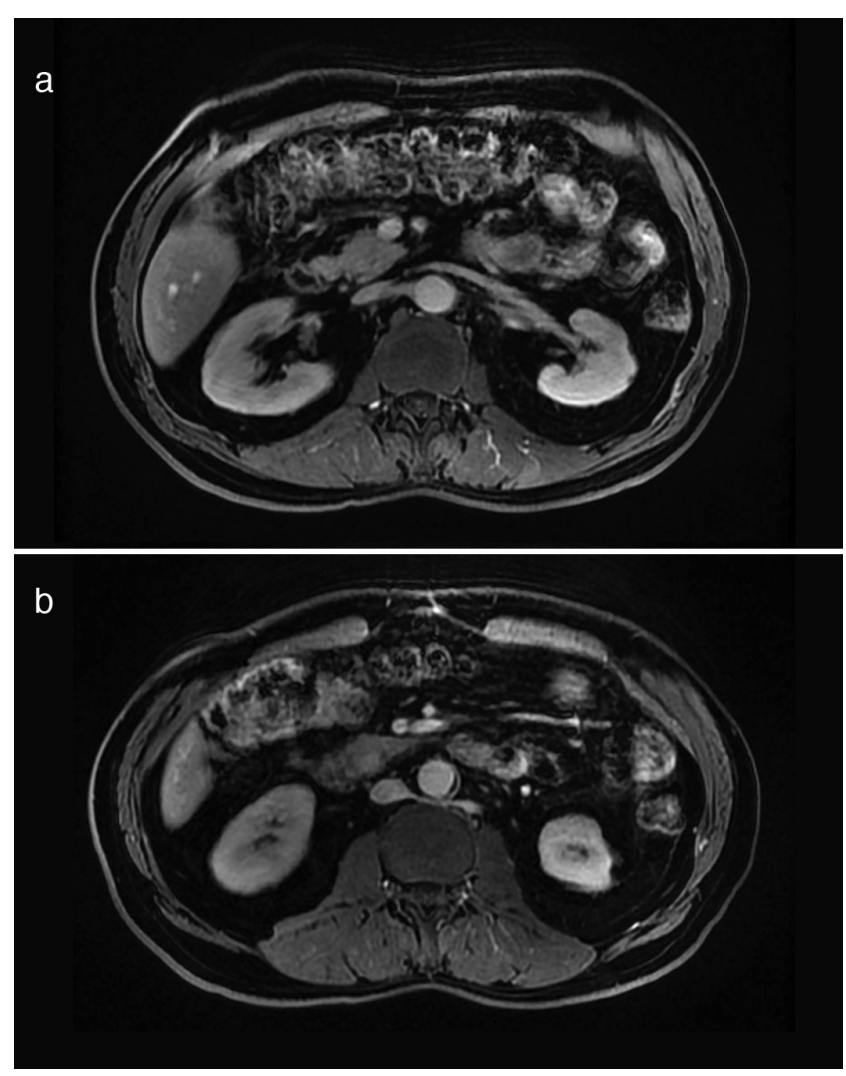

Figure 6. Axial plane MRI showing the circumaortic position of the left renal vein. The left renal vein reaches both the anterior (a) and posterior (b) of the abdominal aorta MRI: Magnetic resonance imaging

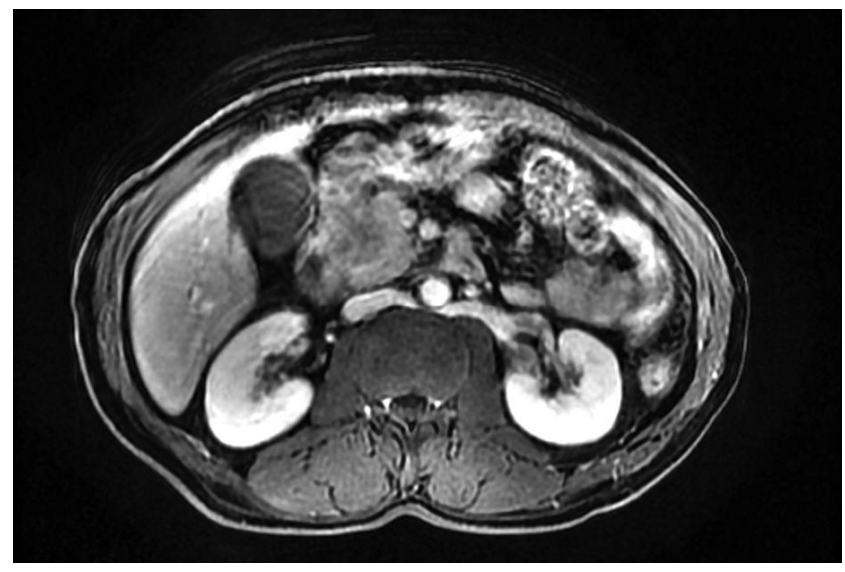

Figure 7. Axial plane MRI showing the retroaortic position of the left renal vein MRI: Magnetic resonance imaging 
Lastly, the mean left renal vein diameter in the renal vein variation group did not differ from that of the control group.

\section{Discussion}

Numerous radiological (with computed tomography or MRI), surgical and post-mortem studies have been conducted to investigate renal vein variations. In these studies, the incidence of retroaortic and circumaortic renal vein variations was reported to be $0.5-17 \%$ and $0.3-6.8 \%$, respectively (3). In the current study, the incidence of left renal vein variations was similar to the values reported in previous studies.

In recent years, DWI has gained increased interest in the evaluation of chronic kidney disease due to the correlation between reduced tissue water diffusion and fibrosis development (11-14). There are many studies in the literature on the $A D C$ values obtained from both patients with diffuse renal parenchymal diseases and individuals with normal renal parenchyma. These studies generally showed that the ADC values in patients with diffuse renal diseases were decreased, and the glomerular filtration rate and renal $A D C$ values were positively correlated in patients with renal dysfunction (15-17). In patients with both acute and chronic renal failure, $A D C$ values are known to decrease. The relationship between reduced $A D C$ and pathological fibrosis development seems to primarily relate to the renal cortex (11-14). Although the literature contains several studies on the renal functions and diffusion values in patients with diffuse renal diseases, to the best of our knowledge, no study has been undertaken to evaluate the effect of renal vascular structures and renal anomalies on ADC values. Therefore, our study is the first and will contribute to the literature in this regard.

In the literature, different $A D C$ values for the right and left kidneys were found in normal kidneys in studies using different devices with different magnetic field strength (1.5 and 3 Tesla) (18-22). However, in some of these studies, the right and left kidney values were not separately reported (19). Kim et al. (18) found that the $A D C$ values of the left kidney were lower than those of the right kidney at high b values using 3 Tesla MRI devices. However, the authors did not provide any information on whether these differences were statistically significant. Similar to our study, Yoshikawa et al. (22) found that the left kidney $A D C$ values were lower than the right kidney values using a1.5 Tesla MRI device. However, they did not present any information about the statistical significance of their results. In contrast, Song et al. (23) determined that the $A D C$ values of the left kidney were higher than those of the right kidney in individuals with healthy renal function. In our study, a difference was found between the right and left kidney ADC values in both the control and renal vein variation groups. However, similar ADC results between these two groups led us to conclude that renal vein variations had no effect on kidney ADC values.

Variations do not cause pressure changes in the renal vein as long as they are asymptomatic. Therefore, we may not have detected the differences in the ADC value between the control and renal vein variation groups in our study. Even if there is a renal vein pressure change that is not causing deterioration in the renal microstructure, may explain why ADC value is not affected. According to our results, it is possible to conclude that renal vein variations do not cause changes in the kidney microstructure as long as they are asymptomatic.

DWI measures the random motion of water molecules, which can be free or restricted by cellular membranes or other barriers (17). It provides microstructural information about tissue microstructure by using the movement of water to probe extracellular and intracellular extravascular spaces (24). However, the $A D C$ value is affected by not only true water diffusion but also microperfusion and tubular flow in the renal tissue (25-27). In the literature, the use of novel DWI models, e.g. intravoxel incoherent motion (IVIM) and diffusion tensor imaging (DTI), in the assessment of diffuse renal pathologies has been investigated. IVIM could provide more accurate information on pseudo diffusion and true diffusion DTI, an advancement of DW MRI, can offer an insight into the structural properties of tissue by assessing the directionality of water diffusion, which is quantified as the percentage of spatially oriented diffusion. Diffusion anisotropy is related to structural organization, and therefore can be compromised in a pathological process (28). The evaluation of the effects of variations using DTI and IVIM can give more accurate information about the pure diffusion effect. In addition, directional information in DTI is an advantage for vascular structures.

\section{Study Limitations}

One of the limitations of our study is that all patients in the group with renal vein variations were asymptomatic. Hematuria and proteinuria were not present in either group. The absence of clinical symptoms in our patients may explain the similarity of the results between the renal vein variation and control groups. Clinically, nutcracker syndrome is observed in a small proportion of patients with renal vein variations. Studies conducted with symptomatic group scan provide more accurate results. There is no consensus on the treatment method for symptomatic patients or the selection of appropriate cases for treatment. Further studies evaluating ADC parameters 
in both symptomatic and asymptomatic groups based on the severity of findings can provide more information concerning the kidney microstructure. ADC values can be one of the parameters that can be considered in treatment selection by providing information about the renal microstructure. The other limitations of our study can be regarded as the relatively low number of patients with renal vein variations. However, this was inevitable considering the low incidence of such variations.

\section{Conclusion}

The patients with renal vein variations and the control group had similar ADC values for both the right and left kidneys. Thus, it can be stated that renal vein variations have no effect on kidney ADC values. However, right and left kidney $A D C$ values being different in groups with and without the renal vein variation should be kept in mind when evaluating this parameter in other conditions.

\section{Authorship Contributions}

Concept: E.G., E.E., M.K. Design: E.G., M.O., M.K. Data Collection or Processing: E.E., M.O. Analysis or Interpretation: E.G., M.K. Literature Search: E.G., E.E., M.O. Writing: $E, G$.

Conflict of Interest: The authors declared no conflicts of interest concerning the authorship and publication of this article.

Financial Disclosure: The authors received no financial support for the research and/or authorship of this article.

\section{References}

1. Dilli A, Ayaz UY, Kaplanoğlu H, et al. Evaluation of the left renal vein variations and and inferior vena cava variations by means of helical computed tomography. Clin Imaging 2013;37:530-5.

2. Zhu J, Zhang L, Yang Z, et al. Classification of the renal vein variations: a study with multidetector computed tomography. Surg Radiol Anat 2015;37:667-75.

3. Pandya VK, Patel AS, Sutariya HC, et al. Evaluation of renal vascular anatomy in live renal donors: Role of multi detector computed tomography. Urol Ann 2016;8:270-6.

4. Karaman B, Koplay M, Ozturk E, et al. Retroaortic left renal vein: multidetector computed tomography angiography findings and its clinical importance. Acta Radiol 2007;48:355-60.

5. Hangge PT, Gupta N, Khurana A, et al. Degree of left renal vein compression predicts nutcracker syndrome. J Clin Med $2018 ; 8 ; 7$.

6. Cuéllar i Calàbria H, Quiroga Gómez S, Sebastià Cerqueda C, et al. Nutcracker or left renal vein compression phenomenon: multidetector computed tomography findings and clinical significance. Eur Radiol 2005;15:1745-51.

7. Cox EF, Buchanan CE, Bradley CR, et al. Multiparametric Renal Magnetic Resonance Imaging: Validation, Interventions, and Alterations in Chronic Kidney Disease. Front Physiol 2017;8:696.

8. Caroli A, Schneider M, Friedli I, et al. Diffusion-weighted magnetic resonance imaging to assess diffuse renal pathology: a systematic review and statement paper. Nephrol Dial Transplant 2018;33:ii29-40.

9. Lanzman RS, Ljimani A, Müller-Lutz A, et al. Assessment of time-resolved renal diffusion parameters over the entire cardiac cycle. Magn Reson Imaging 2018;10;55:1-6.

10. Thoeny HC, De Keyzer F. Diffusion-weighted MR imaging of native and transplanted kidneys. Radiology 2011;259:25-38.

11. Leung G, Kirpalani A, Szeto SG, et al. Could MRI be used to image kidney fibrosis? A review of recent advances and remaining barriers. Clin J Am Soc Nephrol 2017;12:1019-28.

12. Li Q, Li J, Zhang L, et al. Diffusion-weighted imaging in assessing renal pathology of chronic kidney disease: a preliminary clinical study. Eur J Radiol 2014;83:756-62.

13. Morrell GR, Zhang JL, Lee VS. Magnetic resonance imaging of the fibrotic kidney. J Am Soc Nephrol 2017;28:2564-70.

14. Zhao J, Wang ZJ, Liu M, et al. Assessment of renal fibrosis in chronic kidney disease using diffusion weighted MRI. Clin Radiol 2014;69:1117-22.

15. Yalçin-Şafak K, Ayyildiz M, Ünel SY, et al. The relationship of $A D C$ values of renal parenchyma with CKD stage and serum creatinine levels. Eur J Radiol Open 2016;3:8-11.

16. Thiravit S, Suwanchatree P, Skulratanasak $P$, et al. Correlation between apparent diffusion coefficient values of the renal parenchyma and estimated glomerular filtration rates on 3-T diffusion-weighted echo-planar magnetic resonance imaging. J Comput Assist Tomogr 2019;43:780-5.

17. Bedoya MA, Berman JI, Delgado J, et al. Relationship of renal apparent diffusion coefficient and functional MR urography in children with pelvicalyceal dilation. Pediatr Radiol 2019;49:1032-41.

18. Kim BR, Song JS, Choi EJ, et al. Diffusion-weighted imaging of upper abdominal organs acquired with multiple B-value combinations: value of normalization using spleen as the reference organ. Korean J Radiol 2018;19:389-96.

19. Kiliçkesmez O, Yirik G, Bayramoğlu S, et al. Non-breath-hold high b-value diffusion-weighted MRI with parallel imaging technique: apparent diffusion coefficient determination in normal abdominal organs. Diagn Interv Radiol 2008;14:83-7.

20. Lavdas I, Rockall AG, Castelli F, et al. Apparent Diffusion Coefficient of Normal Abdominal Organs and Bone Marrow from Whole-Body DWI at 1.5 T: The Effect of Sex and Age. AJR Am J Roentgenol 2015;205:242-50.

21. Pawluś A, Szymańska K, Łasecki M, et al. Which organ should be considered a reference in diffusion weighted imaging of the abdomen?. The reproducibility of ADC measurements of the spleen and the renal cortex on a 1.5T MR. Adv Clin Exp Med 2017;26:811-16. 
22. Yoshikawa T, Kawamitsu H, Mitchell DG, et al. ADC measurement of abdominal organs and lesions using parallel imaging technique. AJR Am J Roentgenol 2006;187:1521-30.

23. Song JS, Hwang SB, Chung GH, et al. Intra-individual, intervendor comparison of diffusion-weighted MR imaging of upper abdominal organs at 3.0 Tesla with an emphasis on the value of normalization with the spleen. Korean J Radiol 2016;17:209-17.

24. Hagmann $P$, Jonasson L, Maeder P, Thiran JP, Wedeen VJ, Meuli R. Understanding diffusion MR imaging techniques: from scalar diffusion-weighted imaging to diffusion tensor imaging and beyond. Radiographics 2006;26:205-23.

25. Le Bihan $D$, Breton $E$, Lallemand $D$, et al. MR imaging of intravoxel incoherent motions: application to diffusion and perfusion in neurologic disorders. Radiology 1986;161:401-7.
26. Sigmund EE, Vivier PH, Sui D, et al. Intravoxel incoherent motion and diffusion-tensor imaging in renal tissue under hydration and furosemide flow challenges. Radiology 2012;263:758-69, Epub 2012 Apr 20.

27. Wittsack HJ, Lanzman RS, Mathys C, et al. Statistical evaluation of diffusion-weighted imaging of the human kidney. Magn Reson Med 2010;64:616-22.

28. Li XM, Yang L, Reng J, et al. Non-invasive evaluation of renal structure and function of healthy individuals with multiparametric MRI: Effects of sex and age. Sci Rep 2019;9:10661. 